\title{
Phytochemical Screening of Alangium salviifolium (L.f.) Wangerin Showing Antifungal Properties against Alternaria spp.
}

\author{
${ }^{1}$ Aphajal M., ${ }^{2}$ Beg M. Jaish \\ 1,2Department of Botany, Shibli National P.G. College Azamgarh -276001 Uttar Pradesh (India) \\ Corresponding Author: maphajal@gmail.com Mobile: +919889453252
}

\section{Manuscript Details}

Manuscript Submitted : 10/04/2019

Manuscript Revised : :12/04/2019

Manuscript Accepted : 15/04/2019

Manuscript Published : 15/05/2019

\section{$\underline{\text { Available On }}$}

https://plantaescientia.website/ojs

\section{$\underline{\text { Cite This Article As }}$}

M. Aphajal \& Beg M. Jaish (2019). Phytochemical Screening of Alangium salviifolium (L. f.) Wangerin showing antifungal properties against Alternaria spp., Pla. Sci. 2019; Vol. 02 Iss. 01: 01-04. DOI: https://doi.org/10.32439/ps.v2il.1-4

\section{Copyright}

\section{(c) (1)}

(c) The Author (s). 2019. Open Access

This article is distributed under the terms

of the Creative Commons Attribution

4.0 International License

http://creativecommons.org/licenses/by/4.0/

$\underline{\text { Indexed In }}$

Crossref, Index Copernicus International (ICI), Directory of Research Journal Indexing (DRJI), Scientific Indexing Services (SIS),

\section{CiteFactor,}

\section{ABSTRACT}

The antifungal properties shown by different higher plant extracts are due to the presence of phytochemicals. The activities of Alangium salviifolium root in controlling two fungal species that belong to Alternaria spp-Alternaria brassicae and A. brassicicola, the causal organisms of leaf blight of crucifers were evaluated in vitro assay. The aqueous extracts of different parts of tested plant such as bark, stem, root, leaf and flower were screened against test fungi. Among them, the results of the study revealed that the aqueous extracts of A. salviifolium root showed the inhibition of mycelial growth against test fungi completely (100\%). The phytochemical analysis of active plant has revealed that the presence of some chemical compounds as alkaloids, terpenoids, phenol/tannins, saponins, flavonoids and glycosides in both aqueous and ethanol extracts is likely to be responsible for the antifungal activity against test fungi. This study confirms the presence of various bioactive compounds in active plant.

Keywords: Alangium salviifolium, Antifungal, Aqueous extracts, phytochemical analysis and Alternaria spp. 


\section{INTRODUCTION}

The present study was focused on phytochemical properties of Alangium salviifolium root against Alternaria spp.- Alternaria brassicae and A. brassicicola, the causal organisms of leaf blight of crucifers. This active plant Alangium salviifolium belongs to the family Alangiaceae. Locally it is called Akolam or Dhera. Alangiaceae is monogeneric family of trees and shrubs found in tropical and sub-tropical region. Plant extracts were widely screened its medicinal usage. Its dried leaves have traditionally been used to treat various ailments in Asia (Jain et al. 2005). Different parts of this plant are reported to possess acrid, astringent, emollient, anthelmintic, diuretic and purgative properties. It is a popular folk medicine and has been studied for its antioxidants (Jain et al. 2010) and anti-ulcer activities (Subudhi et al. 2012). Plants produce potent constitutive and induce antifungal compounds to complement the structural barriers to microbial infection. Out of over one hundred thousand medicinal plant species around the globe only a small portion has been investigated both phytochemically and pharmacologically (Hostettmann, 1999).

The most common effective method for controlling disease is the use of fungicides but the development of resistance in pathogenic fungi to common fungicides and increasing hazardous residual effect on human health and environment has given a thrust to search for new plant derivatives that can inhibit the fungal pathogenicity. Use of natural products for the management of fungal diseases in the plants is considered as a good alternative to synthetic fungicides, due to their less negative impact on the environment (Gujar, et al. 2012). Root of A. salviifolium is useful for external application in acute case of rheumatism, leprosy and inflammation and internal application in case of bites of rabbits and dogs (Bakhru, 1997) Antibacterial compound was isolated from the flowers of $A$. salviifolium (Ray, 1956). The antimicrobial agents while have been purified and studied prevent fungal growth by different mode of action, some lyse the cells while others block protein synthesis by the susceptible fungi (De Luca et al. 2005). From the above account it is apparent that there is an urgent need to investigate new fungi toxicants which are easily biodegradable and provide inexhaustible resources (Beye, 1978).

\section{MATERIALS AND METHODS}

Collection of Plant Samples: Plant was collected from local area and brought in the laboratory of the Department of Botany, Shibli National PG College Azamgarh (U.P.). The plant was identified with the help of Flora by Duthie, J. F. (1903-1929) and Srivastava, T. N. (1976).
Preparation of aqueous extracts: For fifty percent (w/v) aqueous extracts of each parts of active plant samples were prepared by grinding with sterile distilled water. 40 grams of each plant material was sterilized with $0.1 \% \mathrm{HgCl}_{2}$ solution followed by proper washing with distilled water and was macerated to pulp in a Warring blender. The macerated plant samples were filtered through cheesecloth and finally with Whatman No. 1 filter paper on next day. Thus, a clear extract was prepared for the test of antifungal activity and phytochemical analysis.

Preparation of ethanol extract: 20 grams of sterilized plant sample was taken and crushed to pulp in a warring blender and $100 \mathrm{ml}$ of $50 \%$ ethanol (v/v) was added and stirred with a glass rod and left overnight for dissolving the contents that present in the pulp. Now the pulp in ethanol was filtered through a filter paper to get the extract containing components present in root. Thus, the ethanol extract was prepared for phytochemical analysis.

\section{Procurement of Test Pathogen-Alternaria brassicae (Berk.) Sacc. and A. brassicicola (Schw.) Wiltsh.}

Leaf spot of crucifers are found in all the area of the Azamgarh district. The test fungi were isolated from the infected cruciferous plants. The infected areas of the leaf were cut in the length $(0.5 \mathrm{~cm})$ and dipped in $0.1 \%$ Mercuric chloride $\left(\mathrm{HgCl}_{2}\right)$ solution $(\mathrm{w} / \mathrm{v})$ for one minute to surface sterilize. The infected piece was transferred on Molten Agar Medium as Czapek's Dox Agar Medium (Thom and Raper, 1945) and incubated for 7 days at $24^{\circ} \mathrm{C}$. The fungal colonies growing on the culture plates were identified morphologically on the basis of their colour, type of spores, colony texture and other growth characteristics of the fungi.

Antifungal Assay of Plant Extracts: The sample of plant extracts were assayed for antifungal activity against isolated fungi Alternaria brassicae and A. brassicicola. All the tested plant samples were subjected to antifungal assayed by Poisoned Food Technique (Grover and Moore, 1962 and Mishra and Tiwari, 1992). The extracts of each plant sample was mixed thoroughly with Molten Czapek's Dox Agar medium at $40^{\circ} \mathrm{C}$ in equal amount and poured into sterilized Petri plate at the rate of $10 \mathrm{ml}$ per Petri plate (3" Diameter). For this purpose a mycelial disc (4 $\mathrm{mm}$ in diameter), cut from the periphery of a seven days old culture of the test fungi, using sterilized cork boarer was aseptically transferred at the centre of the Petreplate. Then the plates were incubated at $24^{\circ} \mathrm{C}$ for seven days and observations were recorded. All plates were taken with three replicates and were arranged in completely randomized block design. The screening was repeated throughout the course of the present investigation to confirm the result. On the seventh day, the colony diameter of treatment discs and the control discs were measured in $\mathrm{mm}$ and Percentage of 
inhibition of mycelial growth was determined by using the following formula (Mohana and Raveesha, 2007).

Percentage Mycelial Inhibition $=\frac{\mathrm{C}-\mathrm{T}}{\mathrm{T}} \times 100$

Where, $C$ = Average mycelial growth in control plate $\mathrm{T}=$ Average mycelial growth in treatment plate

\section{Phytochemical Analysis of Alangium salviifolium root in both aqueous and ethanol extracts:}

Phytochemical screening of the plant Alangium salviifolium root extract that showed maximum antifungal activity against Alternaria brassicae and A. brassicicola was carried out using $10 \% \mathrm{w} / \mathrm{v}$ concentrations. The freshly prepared extracts were subjected to standard phytochemical analysis to test for the presence of alkaloids (Mayer's test), terpenoids (Salkowaski test), phenols and tannins (Ferric Chloride test), proteins (Xanthoproteic test), saponins (Frothing test), steroids (Liebermann-Burchard Reaction), flavonoids (Shinoda test) and glycosides.

\section{RESULTS AND DISCUSSIONS}

Different parts of active plant such as bark, stem, root, leaf and flower were collected from the study area (Native of Azamgarh) and their aqueous extracts were assayed for their antifungal activity against two species of Alternaria such as $A$. brassicae and A. brassicicola by poisoned food technique. The result was recorded in Table-1.

Table 1. Percent of mycelial inhibition on different parts of Alangium salviifolium against test fungi.

\begin{tabular}{|l|l|c|c|}
\hline $\begin{array}{l}\text { S. } \\
\text { No. }\end{array}$ & $\begin{array}{c}\text { Different } \\
\text { parts of } \\
\text { Alangium } \\
\text { salviifolium }\end{array}$ & A. brassicae & A. brassicicola \\
\hline 1. & Bark & 88.79 & 91.66 \\
\hline $\mathbf{2 .}$ & Stem & 90.51 & 98.35 \\
\hline 3. & Root & 100.00 & 100.00 \\
\hline $\mathbf{4 .}$ & Leaf & 72.41 & 90.00 \\
\hline 5. & Flower & 96.26 & 98.00 \\
\hline
\end{tabular}

The above table indicated that the aqueous extract of root of Alangium salviifolium showed total inhibition of mycelial growth (100\%) in both the species of Alternaria whereas stem, bark, leaf and flower showed below 100 percent mycelial inhibition against test fungi. Sudhakar et al. (2006) found the significant antifungal activity in the members of the family Fabaceae. Salhi et al. (2017) reported the antifungal properties of aqueous extracts obtained from Artemisia herba-alba, Colula cinera, Asphodelus tenuifolius and Euphoria guyoniana against Fusarium graminearum and F. sporotrichioides. The results of this study revealed that A. herba-alba, C. cinera, A. tenuifolius and E. guyoniana aqueous extract were effective at both concentration of $10 \%$ and $20 \%$ against mycelial growth of Fusarium. Therefore, root extract of Alangium salviifolium was taken for further study and phytochemical analysis was done for the presence of alkaloids, terpenoids, tannins, proteins, saponins, steroids, flavonoids and glycosides and the results were recorded in Table-2

Table 2: Phytochemical analysis of both aqueous and ethanol extract of Alangium salviifolium root

\begin{tabular}{|l|l|c|c|}
$\begin{array}{l}\text { S. } \\
\text { No. }\end{array}$ & Phytochemicals & $\begin{array}{c}\text { Aqueous } \\
\text { extract }\end{array}$ & $\begin{array}{c}\text { Ethanol } \\
\text { extract }\end{array}$ \\
\hline $\mathbf{1 .}$ & Alkaloids & + & + \\
\hline $\mathbf{2}$. & Terpenoids & + & + \\
\hline 3. & Phenols/Tannins & + & + \\
\hline $\mathbf{4}$. & Proteins & - & - \\
\hline 5. & Saponins & + & + \\
\hline 6. & Steroids & - & - \\
\hline 7. & Flavonoids & + & + \\
\hline 8 & Glycosides & + & + \\
\hline
\end{tabular}

$(+)$ indicates presence of phytochemicals and (-) indicates absence of phytochemicals

The phytochemical screening of the plant showed the presence of alkaloids, terpenoids, tannins, saponins, flavonoids and glycosides in both the aqueous and Ethanol extracts. The leaf of A. salviifolium contains alkaloids, terpenoids, saponins, steroids and flavonoids which are to be bioactive anti-diabetic principles and its antioxidant properties (Kalarani et al., 2011). Shinde and Mulay (2015) screened the phytochemical analysis of alcoholic extracts of Azadirachta indica and observed the presence of alkaloids, glycosides, flavonoids, steroids, tannins and reducing sugar which were responsible for antibacterial properties against human pathogens Escherichia coli, Salmonella typhi, Shigella sp. and Staphylococcus aureus. The knowledge of phytochemical constituents is desirable not only for the discovery of therapeutic agent but also disclosing new sources of such economic materials for the synthesis of complex chemical substances (Arkout et al. 2010). The plant chemicals are regarded as secondary metabolites that manufacture them may have little need for them. They are synthesized in all parts of the plant body viz. bark, leaves, stem, root, flower, fruits seeds etc. (Solomon Charles et al. 2013). This chemical work with nutrients and fibers to form an integrated part of defense system against various diseases and stress conditions (Thilagavathi et al. 2015). Minakshi et al. (2016) recorded the phytochemical screening of five plant species viz. Oldenlandia corymbosa, Ricinus communis, Ipomea aquatica, Xanthium strumarium, Mentha piperita and found a variety of 
phytochemicals that have saponins, tannins, flavonoids, terpenoids, glycosides and reducing sugar.

\section{CONCLUSION}

The above results obtained from this investigation showed that active plant root extract screened to exhibit antifungal effect against Alternaria spp. Root of A. salviifolium found out a sources of biofungicide so that environmental hazards can be minimized. The Alangium salviifolium has various medicinal properties and evaluated for the first time its antifungal activity against Alternaria brassicae and Alternaria brassicicola. In the present study, the phytochemical screening for root of Alangium salviifolium showed the presence of active compounds like alkaloids, phenols, tannins, terpenoids, flavonoids and glycosides from aqueous and ethanol extracts. Khalid et al. (2018) investigated the phytochemicals present in the selected medicinal plant viz. Calotropis procera, Lantana camara and Mangifera indica. Flavonoids, tannins, phenolic compounds and alkaloids are the most important bioactive compounds of the plants. It is promising that the tested plant species could be used to synthesize novel fungicide for using against fungal diseases. Further studies are needed to determine chemical identity of the phytochemical compounds responsible for antifungal activity.

\section{ACKNOWLEDGEMENT}

Authors are thankful to the Department of Botany, Shibli National PG College Azamgarh Uttar Pradesh for supporting during this research work.

\section{REFERENCES}

Akrout, A.; El Jani, H.; Zammouri, T.; Mighri, H. and Neffati, M. (2010) Phytochemical Screening and mineral contents of annual plants growing wild in Southern of Tunisia. J. of Phytolog y, 2(1) : 34-40.

Bakhru, H. C. (1997). Herbs that heal. Orient Longman Ltd. pp. 7.

Beye, F. (1978). Insecticides from vegetable kingdom. Plant Research and Development, 7: 13-31.

De Luca, A. J.; Cleveland, T. E. and Wedge, D. E. (2005). Plant-derived antifungal proteins and peptides.Canadian J.Microbiol., 51 : 1001- 1014 https://doi.org/10.1139/w05-063

Duthie, J . F. (1903-1929). Flora of upper Gangetic plain and of the adjacent Siwalik and Sub-Himalayan Tracts.Vol. I-II. Botanical Survey of India, Calcutta. https://doi.org/10.5962/bhl.title.21629

Grover, R. K. and Moore, J .D. (1962). Taximetric studies of fungicides against brown rot organism, Sclerotini a fructicola and S. laxa. Phytopath., 52 : 876-880.

Gujar, J. and Talwankar, D. (2012). Antifungal potential of crude plant extracts on some pathogenic fungi. World J. of Sci. and Tech., 2: 58-62.

Hostettmann, K. (1999). Strategy for the biological and chemical evaluation of plant extracts. Pure Appl. Chem., 70(11):1-9.
Jain, A.; Katewa, S. S.; Galav, P. K. and Sharma, P. (2005). Medicinal plant diversity of Sitamata wildlife sanctuary Rajasthan, India. J. Ethnopharmacol., 102 (2): 143 -157 https://doi.org/10.1016/j.jep.2005.05.047

Jain, V. C.; Patil, N. M.; Shah, D. P.; Patil, P. K. and Hoshi, B. H. (2010) Antioxidant and antimicrobial activity of Alangium salviifolium (L.f.) Wang root. Global J. of Pharm., 4 (1): 13-18.

Kalarani, D.; Dinakar, A. and Senthilkumar, N. (2011). Hypoglycemic and anti-diabetic activity of Alangium salviifolium Wang in Alloxan-induced diabetic rats. Asian J. Pharma. and Clinical Res.,4: 131 -133.

Khalid, S.; Shayad, A.; Basharat, N.; Abubakar, M. and Anwar, P. (2018). Phytochemical Screening and Analysis of Selected Medicinal Plant in Gujrat. J. Phytochemistry Biochem. 2 (1): 108.

Minakshi, B.; Jharna, D; Devi, C. E.; Nayan, T.; Partha, P. K.; Kundal, N. and Manash, P. S. (2016). Phytochemical Analysis of Traditional Medicinal Plants and Their Antimicrobial Activity: An from North East India. J. Pharma. Res. 1(1): 104.

Mishra, N. and Tiwari, S. N. (1992). Toxicity of Polyalthia longifolia against fungal pathogens of rice. Indian Phytopath. 45: 56-61

Mohana; D. C. and Raveesha, K. A. (2007). Antifungal evaluation of some plant extracts against some plant Pathogenic field and storage fungi. J. Agri. Technol., (4)1: 119-137.

Ray, P. C. (1956). History of Chemistry in Ancient and Medical India. Indian Chem. Soc., pp. 36.

Salhi, N.; Saghir, S. A. M.; Terzi, V.; Brahmi, I.; Ghedairi, N. and Bissati, S. (2017) Antifungal Activity of Aqueous Extract of Some Dominant Algerian Medicinal Plants. Bio. Med. Res. Int. 2017: 1-6. https://oi.org/10.1155/2017/7526291

Shinde, A. B. and Mulay Y. R. (2015). Phytochemical Analysis and Antibacterial Properties of Some Selected Indian Medicinal Plants. Int. J. Curr. Microbiology.App. Sci. 4 (3): 228-235.

Solomon, Charles Ugochukwu, Arukwe Uche I. and Ifeanyi, O. (2013). Preliminary phytochemical screening of different solvent extracts of stem bark and root of Dennetia tripetala G. Baker. As. J. Pl. Sci. Res. 3 (3): 10-13.

Srivastava, T. N. (1976). Flora Gorakhpurensis. Today and Tomorrow Printer and Publisher, 1-477.

Subudhi, S. K.; Prusty, K. B. and Panda P. K. (2012). Phytochemical and Anti- ulcer activity of petroleum ether and chloroform extracts of leaves of Alangium n salviifolium Linn. (Family-Alangiaceae). Int. J. of Pharm. Res. and Bio. Sci., 1(2): 102-114.

Sudhakara, M.; Raob, Ch. V.; Raoc, P. M.; Raju D. B. and Venkate swarlud, Y. (2006). Antimicrobial activity of Caesalpinia pulcherrima, Euphorbia hirta and Asystasia gangeticum. Fitoterapia, 77: 378-380. https://doi.org/10.1016/j.fitote.2006.02.011

Thilagavathi, T.; Arvindganth, R.; Vidhya, D.; and Dhivya, R. (2015) Preliminary phytochemical screening of different solvent-mediated medicinal plant extracts evaluated. Int. Res. J. Sharm. 6(4): 246-248. https://doi.org/10.7897/2230-8407.06455

Thom, C. and Raper, K. B. (1945). A manual of the Aspergilli, Williams and W. Wilkins Co., Baltimore, U.S.A.

0 2019| Published by Plantae Scientia 